传及林一雄 長谷川三郎 采野利一 蓠 西 正 男 大 野宗 沉 山闪这 瀨 巨孝一 䜣内六 郎 藤 谷 佳 男 葆原正高 山口昭 七 小南一雄 根本悟 楼 大和田元 田村守 小茷 水利清 丹犸零太郎 他田外茂次 藤本酊入夫 倿边樹 北帠 義 郎 田四神健罗 大谷英三郎 柳 沢信 营 武 正 義 中 村脩 堀英市 森下昭 三 石 橋 保 波多野義治 竹 沢 绐 -
富永物退果京支店 原 料 默 日立製作川崎工場工具課長 舅和工栄 檢查課長 II 檢查課 設計課 日本節絹工場長策製造部長 大和紡松原工場 棈 紡 " I" 緎布科 帝國人編岩國工場 技盛部 小南㿧造鉄工

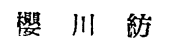
総䇟課長 工教生任 " 嫦業部 鐘紡請㕷所 " 長低工場工務 " 西大寺工場 工 務 日立製作川崎工場 拾查課長 日本フェルト市川工場 工務課長 日本毛䄉用南工場 紡 績 科 大日本紡・関原工場

\section{會費有効期限 と}

\section{4年度會費拂込おねがい}

昭和 23 年度会費は入会月より 1 年間侍効で すが，去る4月より新年度会費が倍額になり ましたので下記の如く有效期限が変りますか ら御含みの上，期限前に24年度新会費を御拂 达下さん。

昭和 23 年 6 月入会の場合 24年 4 月まで

$$
7 \sim 8 \text { 月 " }
$$

5 月まで

$9 \sim 10$ 月 '6月まで

11 12月

7 月まて

8月まで 9 月まで
小林荘

㣬 野 昭三 丸江工栄

技術部

學生會員

馬場昭一名古屋工專紡織

\section{會員異動}

東亞金属工業株式会社 (賀) は紡機製造株式会祀之社名 変更

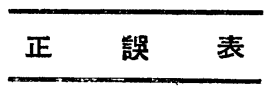

第8號 (1949年4 月号) (今村氏論文)

\begin{tabular}{|c|c|c|c|c|}
\hline 頁 & 側 & 行 & 正 & 是 \\
\hline 5 & 左 & 下和万 3 行目 & 4 図に示す通 & 3 图に示す通 \\
\hline " & 右 & 16行目 & 第 4 図右 & 第 4 四左 \\
\hline & "I & 18行目 & 左図 & 右四 \\
\hline & "I & 23行目 & 左図 & 右図 \\
\hline & "I & 27 行目 & 左図 & 右図 \\
\hline & 右 & 下から 10行目 & Front & 2nd Front \\
\hline & 右 & 25行目 & 待時間が & 傳時間方， \\
\hline
\end{tabular}

第8號(4 月号) (㫌沢, 上森氏論文)

10 頁の第 5 因火糸層牛径 $\mathrm{r}$ を書入れ ること。

11 貝右側 19 行目よりの数式は资の裸に訂正のとと

$\mathrm{M}_{\mathrm{t}}=-2 \mathrm{~T} l_{\mathrm{d} c}\left[\operatorname{os} \phi\left\{\left(l_{\mathrm{f}} / l_{\mathrm{j}}\right) \cdot \sin \phi \sin \right\rangle+\cos \right.$

$(\phi+\mu+\lambda)[+\cos (\tau / 4+\delta / 2+\alpha / 2)$

$\cdot \cos (\Theta+\pi / 4+\delta / 2-\alpha / 2)] \cdot \cdots \cdot(3)$

\begin{tabular}{|c|c|c|c|c|}
\hline 10 & 右 & 2 & レギュレーション & コネクチン \\
\hline 12 & 左 & 2 & $\Theta$ & $\theta$ \\
\hline "I & "I & 4 & $\iota_{\mathrm{d}}$ & $l \mathrm{~d}$ \\
\hline "I & "I & 5 & $\Theta-B$ & $\theta+B$ \\
\hline 13 & 左 & 1 & $2 \omega+\varepsilon_{0}$ & $2 \omega-\xi_{0}$ \\
\hline 13 & 右 & 4 & $r=r_{0}$ & $r=r$ \\
\hline "I & "I & 5 & $r=r_{0}$ & $r={ }_{0} r$ \\
\hline
\end{tabular}

(正) $\mathrm{dn} / \mathrm{d} B, \mathrm{dMt}_{\mathrm{t}} / \mathrm{d} B, \mathrm{dM} / \mathrm{d} B$,

(誤) $\mathrm{dn} / \mathrm{d} B, \mathrm{~d}_{\mathrm{M}} / \mathrm{d} \beta, \mathrm{d} M / \mathrm{d}_{\mathrm{B}}^{\prime}$, । $\mathrm{M}$ と $\mathrm{t}$

Mと $\mathrm{Mt}^{\mathrm{t}}$

制限してるる。 制限してるる

昭利24年6月10日箃行定價金60 国

蹁集策發行人

印 殿 所 送种 3 圆 上野 達也 大阪市北區芝田町 65 新日本印刷芝田工堨

大阪市南區難波新地 2 番丁 28

得 行 所

日本緎維機械学会 羊 南 (75) 2893 